Article

\title{
Occurrence, Seasonal Abundance, and Superparasitism of Ooencyrtus kuvanae (Hymenoptera: Encyrtidae) as an Egg Parasitoid of the Spotted Lanternfly (Lycorma delicatula) in North America
}

\section{Houping Liu}

Pennsylvania Department of Conservation and Natural Resources, Harrisburg, PA 17105, USA; hliu@pa.gov; Tel.: +1-717-425-7553

Received: 4 December 2018; Accepted: 15 January 2019; Published: 22 January 2019

check for

Abstract: The occurrence of egg parasitoid Ooencyrtus kuvanae (Howard) (Hymenoptera: Encyrtidae) on its new host, the spotted lanternfly (Lycorma delicatula (White) (Hemiptera: Fulgoridae)), was surveyed at 4 study plots in 2016 and 10 additional plots in 2017 in Pennsylvania through field collection and laboratory incubation. O. kuvanae adults were found on L. delicatula egg mass surfaces at two plots (ODSouth and Lutz) in 2016, but at none in 2017. The results of laboratory incubation showed that $O$. kuvanae adults were only recovered from host eggs collected at plot ODSouth in 2016, with adults emerging between 22 April and 2 May 2016 at $22 \pm 1{ }^{\circ} \mathrm{C}, 40 \% \pm 5 \%$ relative humidity $(\mathrm{RH})$, and a 16:8 $\mathrm{h}$ photoperiod (light/dark). The overall parasitism at this study plot was $6.0 \%$ by egg mass and $1.2 \%$ by egg. Two oviposition sites contained parasitized L. delicatula eggs, with $12.3 \%(9.5-15.0 \%)$ host egg masses and 3.1\% (1.3-5.0\%) host eggs utilized by the parasitoid. O. kuvanae parasitism by egg was significantly higher on oviposition site ODSouth \#7 than on ODSouth \#8. No O. kuvanae adults were reared out of field-collected host eggs from the 10 plots in 2017. Seasonal abundance and superparasitism of O. kuvanae was examined at plot ODSouth in 2017. O. kuvanae-parasitized L. delicatula eggs were found on all four oviposition sites based on field monitoring of parasitoid adult emergence, resulting in a parasitism of $35.4 \%$ (18.8-55.6\%) by egg mass and $2.2 \%(0.5-3.9 \%)$ by egg. No significant difference in parasitism by egg was observed among oviposition sites. O. kuvanae adults emerged in the field between 2 May and 1 June 2017. Superparasitism was confirmed for O. kuvanae on L. delicatula eggs based on parasitoid production (1.0-3.3 adults/parasitized egg) and adult exit holes (1-3 exit holes/parasitized egg). As the first parasitoid recorded from L. delicatula in North America, O. kuvanae has the potential to become an important biological control agent for L. delicatula in North America, with its well-synchronized life history in the spring, century-long field establishment, superparasitism, and female-biased progeny population. L. delicatula complements the gypsy moth well as an alternative host for O. kuvanae in the field.

Keywords: Ooencyrtus kuvanae; occurrence; seasonal abundance; superparasitism; spotted lanternfly; North America

\section{Introduction}

The spotted lanternfly, Lycorma delicatula (White) (Hemiptera: Fulgoridae), a sporadic pest of tree-of-heaven, Ailanthus altissima (Mill.) Swingle (Simaroubaceae), in its native range of China, Taiwan, and Vietnam [1-4], was first discovered in North America near Boyertown (40.33366 N, 75.63744 W) in Berks county, Pennsylvania, in 2014 [5,6]. It is now found in multiple counties in Pennsylvania, Virginia, 
New Jersey, New York, and Delaware [7-11]. Recorded host species include more than 70 woody plants and vines in 25 families, such as grape, apple, hops, birch, cherry, lilac, maple, poplar, and stone fruits $[3,6,12]$. Both nymphs and adults feed on phloem tissue that causes oozing wounds on trunks and branches, resulting in wilting or the death of branches under high pest population levels. Large amounts of honeydew are excreted and deposited on host trees and the understories during feeding, promoting the growth of sooty mold that hinders plant photosynthesis and contaminates agricultural and forest crops $[4,5]$. Mold-contaminated crops are deemed unmarketable. Significant damage has been recorded in vineyards in Korea since its initial introduction in 2004 [4,13,14]. In Pennsylvania, this invasive insect pest is directly threatening the state's \$18-billion fruits, nursery and landscape, and hardwood industries. Profound impacts are also expected on the livelihoods of local producers and businesses and the quality of life of the residents in the infested areas [15].

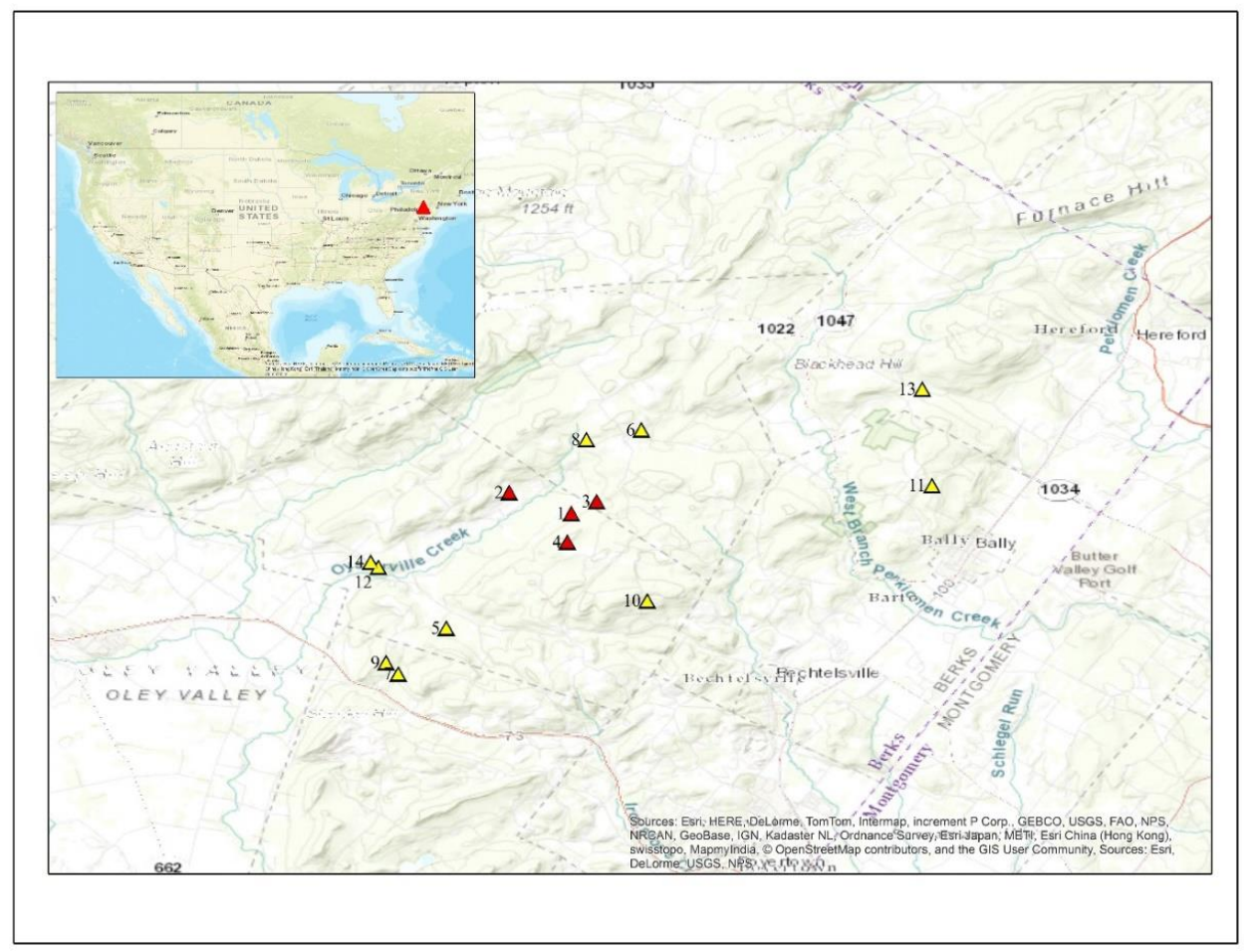

Figure 1. Plot map of Ooencyrtus kuvanae studies on Lycorma delicatula in Berks County, Pennsylvania.

$\Delta_{2016 ;} \Delta_{2017}$ 1. Rolling (epicenter); 2. ODSouth; 3. Rock; 4. Lutz; 5. Straub; 6. Conrad; 7. WSEast; 8. ODNorth; 9. WSWest; 10. Nuss; 11. Kulps; 12. HCEast; 13. Huffs; 14. HCWest.

In China, L. delicatula completes one generation per year and overwinters as eggs on tree trunks, rocks, or man-made structures nearby. Eggs start to hatch in mid-April with a peak in early May. Nymphs pass through four instars to become adults between mid-June and early July. Adults mate and lay eggs in mid-August. Eggs are laid in masses arranged in 5-10 rows with 10-30 eggs/row and covered by gray wax. Both nymphs and adults are good hoppers that aggregate on leaves and tree trunks [3]. In Korea, nymphs appear in May and develop into adults in late July, with egg laying starting in August and lasting until early November [14,16]. A similar life cycle has also been observed in Pennsylvania for this pest, except eggs did not appear in the field until mid-October [6].

Ooencyrtus kuvanae (Howard) (Hymenoptera: Encyrtidae) is a solitary egg parasitoid of the gypsy moth (Lymantria dispar (L.) (Lepidoptera: Erebidae)) from Japan [17]. Other lepidopteran hosts in the field for this parasitoid in its native range include Dendrolimus spectabilis Butler (Lasiocampidae) [18] and Eriogyna pyretorum Westwood (Saturniidae) [19]. As a hyperparasitoid, it also attacks gypsy moth egg parasitoid Anastatus disparis Ruschka (Hymenoptera: Eupelmidae) and larval parasitoid Apanteles melanoscelus Ratzeburg (Hymenoptera: Braconidae) [20,21]. 
O. kuvanae was first introduced to the Unites States in 1908 for gypsy moth biological control [22]. The gypsy moth is native to most of temperate Europe and Asia. It was accidentally introduced to Massachusetts in 1869. By the 1930s, it was widespread in all six New England states (Maine, Vermont, New Hampshire, Massachusetts, Connecticut, and Rhode Island), as well as in eastern New York and regions of New Jersey [23]. The successful establishment of O. kuvanae was first achieved in Massachusetts in 1911 [24]. Since then, millions of O. kuvanae have been reared and released throughout the areas infested by gypsy moths in North America [25]. The release and subsequent recovery of O. kuvanae in Pennsylvania occurred between 1969 and 1971 [26]. In 2016, O. kuvanae was confirmed as an egg parasitoid of $L$. delicatula based on genetic and morphological features of adults collected from the field as well as reared out of host eggs in the laboratory [27]. This was the first report of O. kuvanae as a primary parasitoid of a non-lepidopteran host.

Superparasitism refers to the oviposition behavior of a female parasitoid in a host already parasitized by itself (self-superparasitism) or a conspecific female (conspecific superparasitism) [28-32]. It is an adaptive reproductive strategy commonly found in both solitary and gregarious parasitoids when multiple parasitoid progenies are found in a single host. The incidence of superparasitism for O. kuvanae was recently reported on Philosamia ricini Donovan (Lepidoptera: Saturniidae) under laboratory conditions [33]. This phenomenon was also reported for O. kuvanae on field-collected gypsy moth larval parasitoid A. melanoscelus pupae [20] and laboratory-reared pine tussock moth Dasychira pinicola Dyar (Lepidoptera: Erebidae) eggs [34], although the term "superparasitism" was not used in those publications.

In this study, the occurrence of O. kuvanae as an egg parasitoid of L. delicatula was surveyed at multiple field plots over two years. Its seasonal abundance was monitored through laboratory incubation of parasitized host eggs and field observation of marked host eggs. Evidence of superparasitism was examined through parasitoid production and adult exit holes on host eggs after laboratory incubation.

\section{Materials and Methods}

\subsection{Field Plots}

Fourteen 0.4-ha plots in Berks County, Pennsylvania, were selected for this study, including four (Rolling, ODSouth, Rock, and Lutz) from the core infestation in 2016, and 10 (Straub, Conrad, WSEast, ODNorth, WSWest, Nuss, Kulps, HCEast, Huffs, and HCWest) from the immediate outskirts of the core in 2017 (Figure 1). Plot Rolling was the infestation epicenter of L. delicatula in North America in 2014 [5]. All but two plots (ODSouth and WSEast) were from mixed hardwood forests dominated or co-dominated by red maple (Acer rubrum L.), black birch (Betula lenta L.), black cherry (Prunus serotina Ehr.), northern red oak (Quercus rubra L.), tree-of-heaven, tulip tree (Liriodendron tulipifera L.), and white ash (Fraxinus americana L.). Other understory species observed at those plots included American hornbeam (Carpinus caroliniana Walter), yellow birch (Betula alleghaniensis Britt.), river birch (Betula nigra L.), sweet cherry (Prunus avium L.), sassafras (Sassafras albidum (Nuttall) Nees), shagbark hickory (Carya ovata (Mill.) K. Koch), eastern white pine (Pinus strobus L.), white oak (Quercus alba L.), silver maple (Acer saccharinum L.), Norway maple (Acer platanoides L.), boxelder (Acer negundo L.), and blackhaw (Viburnum prunifolium L.). Plot ODSouth was located inside a family farm with hedgerows dominated by black cherry, flowering dogwood (Cornus florida L.), and bitternut hickory (Carya cordiformis (Wangenh.) K. Koch), whereas plot WSEast was the backyard of a residence scattered with single tree-of-heaven and black walnut (Juglans nigra L.) trees in the middle, and northern spicebush (Lindera benzoin L.) along the edges.

\subsection{Egg Collection}

Field sampling was carried out between the end of March and mid-April to ensure overwintering O. kuvanae adults were active and had the chance to parasitize L. delicatula eggs in the field. 
Egg collection in 2016 was conducted at four plots (Rolling, ODSouth, Rock, and Lutz) between 30 March and 6 April. At each plot, potential L. delicatula oviposition sites (trunks of live or dead trees, shrubs, vines, rocks, fence posts, building structures, etc.) were searched for egg masses. Egg masses found on low 2-m tree trunks or vines and shrubs were collected using a 1.27-cm (1/2-inch) bench chisel (Buck Brothers, Everett, WA). To collect egg masses on bark, two direct cuts, one $5 \mathrm{~mm}$ above and one $5 \mathrm{~mm}$ beneath them, were first created. The egg masses were then dislodged by gently pushing the chisel under the bark upwards from the lower end. Care was taken to make sure no eggs were accidentally missed, cut, squeezed, or otherwise damaged. Egg masses found on other oviposition sites (rocks, fence posts, building structures) were gently removed from beneath with a pair of $118-\mathrm{mm}$ blunt featherweight forceps (BioQuip, Rancho Dominguez, CA). Each dislodged egg mass was held inside a 100-mm petri dish (VWR International, Radnor, PA) before being transferred into a 16-mL borosilicate clear glass vial with a black phenolic cap (Fisher Scientific, Hampton, NH). Egg masses were held individually in the vials and labeled by plot name, oviposition site number, and egg mass number (e.g., ODSouth \#7-2 represented the second egg mass collected from oviposition site No. 7 at plot ODSouth). A total of six man-hours (three skilled surveyors for two hours) was spent to collect L. delicatula egg masses at each plot. No egg masses from chemically treated tree-of-heaven trees were collected.

Egg collection in 2017 was carried out at 10 plots (Straub, Conrad, WSEast, ODNorth, WSWest, Nuss, Kulps, HCEast, Huffs, and HCWest) between 12 and 26 April following the same collecting protocols as described above, except egg masses were held individually in 50-mL centrifuge tubes (VWR International, Radnor, PA) after being collected.

\subsection{Egg Incubation}

Field-collected L. delicatula egg masses were brought back to the laboratory for incubation inside Percival incubators (model \# DR-36VL, Percival Scientific, Perry, IA) at $22 \pm 1{ }^{\circ} \mathrm{C}, 40 \% \pm 5 \%$ relative humidity (RH), and a 16:8 h photoperiod (light/dark) for two months. This process was done in the quarantine laboratory at the United States Department of Agriculture-Agricultural Research Service (USDA-ARS) Beneficial Insects Introduction Research (BIIR) in Newark, DE, in 2016, and at the Pennsylvania Department of Conservation and Natural Resources (DCNR) field laboratory in Boyertown, PA, in 2017.

\subsection{Occurrence of O. kuvanae}

Occurrence of O. kuvanae was observed through field collections and laboratory rearing between 2016 and 2017. In the field, during egg collection at the 14 plots, L. delicatula oviposition sites were examined for potential egg parasitoid adults. Parasitic wasps found actively searching and probing on the surface of L. delicatula egg masses were collected and brought back to the laboratory for identification. In addition, field-collected L. delicatula eggs were incubated in the laboratory for O. kuvanae adults. Adult emergence was monitored daily between 31 March and 5 May in 2016 and 12 April and 17 May in 2017. Numbers of O. kuvanae adults emerged were recorded by date and egg mass number.

\subsection{Seasonal Abundance of O. kuvanae}

Seasonal abundance of O. kuvanae was evaluated at plot ODSouth since it was the only plot where parasitized host eggs were recovered from field-collected host eggs in 2016. Daily adult emergence during laboratory incubation was recorded in 2016. A total of 83 egg masses from nine oviposition sites at plot ODSouth were incubated in 2016. For 2017, O. kuvanae seasonal abundance was estimated by monitoring a group of potentially parasitized host egg masses in the field throughout the season. Periodic sampling followed by laboratory incubation was not attempted to preserve this fringe O. kuvanae field population. A total of 41 egg masses (EM-1 to EM-41) from four oviposition sites at plot ODSouth were marked at the beginning of the 2017 season. O. kuvanae adult emergence on those 
egg masses was monitored every 2-4 days between 2 May and 15 June. The number of parasitized eggs from each egg mass was recorded on each date. Parasitized eggs were easily recognized by round exit hole(s) on the host egg surface with the help of a $30 \times$ hand lens.

\subsection{Parasitism of O. kuvanae}

O. kuvanae parasitism was calculated by egg mass (number of egg masses parasitized/total number of egg masses) and egg (number of eggs parasitized/total number of eggs) for plot ODSouth only, since no parasitoid adults were reared out of $L$. delicatula eggs collected from other plots. Parasitism was also calculated by egg mass and egg for individual oviposition site at this plot. Oviposition sites containing no parasitized L. delicatula eggs were excluded from parasitism calculation to simplify data analysis. Parasitism in 2016 was based on laboratory incubation of parasitized L. delicatula eggs, whereas parasitism in 2017 was calculated based on observation of parasitoid emergence from L. delicatula eggs on oviposition sites in the field.

\subsection{Superparasitism in O. kuvanae}

To determine whether superparasitism occurred for O. kuvanae on L. delicatula, field-collected host eggs were examined under a dissecting scope for parasitoid adult emergence and number of exit holes on each parasitized host egg. The number of $O$. kuvanae adults emerged, the number of host eggs parasitized for each egg mass, and the number of parasitoid exit holes on each parasitized host egg were recorded. Superparasitism occurred when the total number of $O$. kuvanae obtained from a host egg mass was greater than the total number of parasitized host eggs in it. Evidence of superparasitism was further examined by parasitoid exit holes registered on each parasitized egg. Multiple parasitoid exit holes on a single host egg indicated multiple adult emergences and hence superparasitism.

\subsection{Identification of O. kuvanae}

Adult specimens were initially identified by Dr. Jason Mottern (USDA ARS Systematic Entomology Laboratory, Washington, DC, USA) using the key to species in Huang and Noyes [35]. This identification was further confirmed by morphological comparison with $O$. kuvanae specimens in the United States National Museum of Natural History (USNM) collection and the results of gene sequencing [27]. Images were also sent to Dr. John Noyes at the Natural History Museum, London, who concurred with the initial identification. All specimens were deposited in the USNM and DCNR Entomology Collection.

\subsection{Data Analysis}

A generalized linear model (GLM) with a binomial distribution was fitted in $\mathrm{R}$ to examine the effect of oviposition site on O. kuvanae parasitism by egg [36]. No comparison on parasitism was made between years since different sampling methods were used.

\section{Results}

\subsection{Egg Collection}

A total of 663 L. delicatula egg masses (22,202 eggs) were collected from 208 oviposition sites for this study over two years, including 262 egg masses (8282 eggs) from 97 oviposition sites at 4 study plots in 2016 and 401 egg masses (13,920 eggs) from 111 oviposition sites at 10 study plots in 2017 (Table 1). L. delicatula egg masses were found on all sorts of oviposition sites, including various live and dead trees, shrubs, building structures, fence posts, rocks, etc. Major oviposition sites for L. delicatula recorded at each plot ranged from tree-of-heaven (Lutz, Straub, Conrad, Kulps, Huffs, and HCWest) to black birch (Rolling and Nuss), black cherry (ODSouth and HCEast), yellow birch (Rock), tulip trees (ODNorth), sweet cherry (WSWest), and even metal fence posts (WSEast) (Table 1). Tree-of-heaven was found in all study plots either as single trees, in pockets, or scattered in the woods. Dominant tree 
species at each study plot were not necessarily the most used oviposition sites by L. delicatula females, although tree-of-heaven would have been preferred if the majority of them were not preemptively excluded at most plots due to chemical or mechanical control (Table 1). Mechanical and chemical control of tree-of-heaven was implemented as part of L. delicatula management at all but two of the study plots (Table 1).

Table 1. L. delicatula egg collection for natural enemy studies in Pennsylvania in 2016-2017.

\begin{tabular}{|c|c|c|c|c|c|c|c|}
\hline \multirow{2}{*}{ Plot Name } & \multirow{2}{*}{$\begin{array}{l}\text { Oviposition } \\
\text { Sites } \\
\text { Examined }\end{array}$} & \multirow{2}{*}{$\begin{array}{l}\text { Dominant } \\
\text { Site }\end{array}$} & \multirow{2}{*}{$\begin{array}{l}\text { No. Egg } \\
\text { Masses }\end{array}$} & \multirow{2}{*}{ No. Eggs } & \multicolumn{2}{|c|}{ Tree-of-Heaven } & \multirow{2}{*}{ Note } \\
\hline & & & & & Distribution $^{a}$ & Treatment $^{b}$ & \\
\hline \multicolumn{8}{|l|}{2016} \\
\hline Rolling & 50 & Black birch & 79 & 2482 & Pockets & Chemical & $\begin{array}{c}\text { Infestation } \\
\text { epicenter-mixed } \\
\text { hardwood dominated by } \\
\text { red maple and black } \\
\text { cherry }\end{array}$ \\
\hline ODSouth & 9 & Black cherry & 83 & 3013 & Single trees & Chemical & $\begin{array}{l}\text { Family farm with } \\
\text { hedgerows of flowering } \\
\text { dogwood and black } \\
\text { cherry }\end{array}$ \\
\hline Rock & 25 & Yellow birch & 40 & 1108 & Scattered & Chemical & $\begin{array}{l}\text { Mixed hardwood } \\
\text { dominated by black } \\
\text { cherry and red maple }\end{array}$ \\
\hline \multirow[t]{2}{*}{ Lutz } & 13 & Tree-of-heaven & 60 & 1679 & Pockets & None & $\begin{array}{l}\text { Mixed hardwood } \\
\text { dominated by northern } \\
\text { red oak and black cherry }\end{array}$ \\
\hline & 97 & & 262 & 8282 & & & \\
\hline \multicolumn{8}{|l|}{2017} \\
\hline Straub & 16 & Tree-of-heaven & 43 & 1165 & Scattered & Mechanical & $\begin{array}{l}\text { Mixed hardwood } \\
\text { dominated by northern } \\
\text { red oak and tulip tree } \\
\text { Mixed hardwood }\end{array}$ \\
\hline Conrad & 7 & Tree-of-heaven & 19 & 638 & Pockets & Mechanical & $\begin{array}{c}\text { dominated by } \\
\text { tree-of-heaven and tulip } \\
\text { tree }\end{array}$ \\
\hline WSEast & 12 & $\begin{array}{l}\text { Metal fence } \\
\text { post }\end{array}$ & 57 & 2085 & Single trees & Chemical & $\begin{array}{c}\text { Single yard trees of } \\
\text { tree-of-heaven and black } \\
\text { walnut }\end{array}$ \\
\hline ODNorth & 8 & Tulip tree & 18 & 490 & Scattered & Chemical & $\begin{array}{l}\text { Mixed hardwood } \\
\text { dominated by red maple } \\
\text { and black cherry } \\
\text { Mixed hardwood }\end{array}$ \\
\hline WSWest & 1 & Sweet cherry & 52 & 2573 & Scattered & Chemical & $\begin{array}{l}\text { dominated by red maple } \\
\text { and northern red oak }\end{array}$ \\
\hline Nuss & 18 & Black birch & 27 & 858 & Scattered & Chemical & $\begin{array}{l}\text { Mixed hardwood } \\
\text { dominated by red maple } \\
\text { and northern red oak }\end{array}$ \\
\hline Kulps & 22 & Tree-of-heaven & 57 & 1845 & Scattered & Mechanical & $\begin{array}{l}\text { Mixed hardwood } \\
\text { dominated by red maple } \\
\text { and northern red oak } \\
\text { Mixed hardwood }\end{array}$ \\
\hline HCEast & 13 & Black cherry & 51 & 1919 & Pockets & None & $\begin{array}{l}\text { dominated by } \\
\text { tree-of-heaven and red } \\
\text { maple }\end{array}$ \\
\hline Huffs & 7 & Tree-of-heaven & 14 & 523 & Scattered & Mechanical & $\begin{array}{l}\text { Mixed hardwood } \\
\text { dominated by northern } \\
\text { red oak and red maple }\end{array}$ \\
\hline \multirow[t]{3}{*}{ HCWest } & 7 & Tree-of-heaven & 63 & 1824 & Pockets & Mechanical & $\begin{array}{l}\text { Mixed hardwood } \\
\text { dominated by } \\
\text { tree-of-heaven and white } \\
\text { ash }\end{array}$ \\
\hline & 111 & & 401 & 13920 & & & \\
\hline & 208 & & 663 & 22202 & & & \\
\hline
\end{tabular}

a "Pockets" is defined as groups of at least five mature tree-of-heaven trees at each location inside the mixed hardwood forest, whereas "scattered" refers to single tree-of-heaven trees found throughout the forest. ${ }^{b}$ Chemical: Triclopyr through hack-and-squirt (large trees) or spray (small trees); mechanical: Felling and chipping trees.

\subsection{Occurrence of O. kuvanae}

The results of the field collections indicated that O. kuvanae presented at two of the four study plots in 2016. A total of 33 adults were collected on the surface of L. delicatula egg masses in 2016, 
including 30 from four black cherry trees at plot ODSouth and three from a single black cherry tree at plot Lutz. No O. kuvanae adults were found at the other plots in 2016.

O. kuvanae adults were recovered from L. delicatula eggs collected at plot ODSouth based on laboratory incubation in 2016. A total of 83 egg masses (3103 eggs) were collected from nine oviposition sites at this plot (Table 1). However, O. kuvanae was only recovered from two oviposition sites (Table 2). Five of the 41 egg masses (1507 eggs) from those two sites were parasitized, including 3 out of the 20 egg masses from oviposition site ODSouth \#7 and 2 out of the 21 egg masses from oviposition site ODSouth \#8 (Table 2). Among the 186 total eggs from those five parasitized egg masses, 37 eggs were utilized by $O$. kuvanae, including 28 from oviposition site ODSouth \#7 and 9 from oviposition site ODSouth \#8 (Table 2).

No O. kuvanae adults were found at the 10 plots in 2017 through field collections. No O. kuvanae adults were recovered from field-collected L. delicatula eggs at any plot either based on the results of laboratory incubation in 2017.

For the 41 egg masses (1726 eggs) on 4 oviposition sites monitored at study plot ODSouth in 2017, O. kuvanae adult exit holes were found on 13 of them, including 3 out of 16 from oviposition site A, 3 out of 11 from oviposition site B, 5 out of 9 from oviposition site $C$, and 2 out of 5 from oviposition site $\mathrm{D}$ (Table 2). A total of $37 \mathrm{~L}$. delicatula eggs were parasitized from those $13 \mathrm{egg}$ masses (containing a combined total of 634 eggs), with the highest number of parasitized eggs (17) found on oviposition site A, where 3 egg masses were parasitized (Table 2). A total of 3, 13, and 4 L. delicatula eggs were parasitized on oviposition sites $B, C$, and D, respectively (Table 2).

Table 2. O. kuvanae parasitism on L. delicatula eggs by oviposition site at plot ODSouth based on laboratory incubation (2016) and field observation (2017).

\begin{tabular}{|c|c|c|c|c|c|c|c|c|}
\hline \multirow[b]{2}{*}{ Site No. } & \multirow[b]{2}{*}{ Species } & \multirow{2}{*}{$\begin{array}{c}\mathrm{DBH}^{a} \\
(\mathrm{~cm})\end{array}$} & \multicolumn{3}{|c|}{ By Egg Mass } & \multicolumn{3}{|c|}{ By Egg } \\
\hline & & & Total & Parasitized & $\begin{array}{c}\text { Parasitism } \\
\left(_{(\%)}^{b}\right.\end{array}$ & Total & Parasitized & $\begin{array}{l}\text { Parasitism } \\
(\%)^{c}\end{array}$ \\
\hline \multicolumn{9}{|l|}{2016} \\
\hline \#7 & Black cherry & 7.5 & 20 & 3 & 15.0 & 653 & 28 & $5.0 \pm 45.3$ \\
\hline \multirow[t]{2}{*}{$\# 8$} & Black cherry & 10.0 & 21 & 2 & 9.5 & 854 & 9 & $1.3 \pm 5.5$ \\
\hline & & & 41 & 5 & $12.3 \pm 1.9$ & 1507 & 37 & $3.1 \pm 11.7$ \\
\hline \multicolumn{9}{|l|}{2017} \\
\hline A & White ash & 25.4 & 16 & 3 & 18.8 & 600 & 17 & $2.5 \pm 6.7$ \\
\hline B & $\begin{array}{c}\text { Flowering } \\
\text { dogwood } \\
\text { (dead) }\end{array}$ & 30.8 & 11 & 3 & 27.3 & 503 & 3 & $0.5 \pm 0.8$ \\
\hline $\mathrm{C}$ & Black cherry & 17.8 & 9 & 5 & 55.6 & 378 & 13 & $3.9 \pm 6.9$ \\
\hline \multirow[t]{2}{*}{$\mathrm{D}$} & $\begin{array}{l}\text { Flowering } \\
\text { dogwood }\end{array}$ & 35.6 & 5 & 2 & 40.0 & 245 & 4 & $2.2 \pm 4.3$ \\
\hline & & & 41 & 13 & $35.4 \pm 15.0$ & 1726 & 37 & $2.2 \pm 5.4$ \\
\hline
\end{tabular}

$\overline{{ }^{a} \mathrm{DBH}-\text { diameter at breast height }(1.3 \mathrm{~m}) ;{ }^{b} \text { parasitism by egg mass }(\%)=(\text { number of egg masses parasitized/total }}$ number of egg masses) $\times 100 \%{ }^{c}$ parasitism by egg $(\%)=$ (number of eggs parasitized / total number of eggs in the egg mass) $\times 100 \%$.

\subsection{Seasonal Abundance of O. kuvanae}

In 2016, O. kuvanae adult emergence started on 22 April and ended on 2 May based on laboratory incubation of field-collected L. delicatula eggs, with three overall peaks on 25 April, 28 April, and 2 May (Figure 2). For L. delicatula egg masses collected from oviposition site ODSouth \#7, parasitoid adults emerged between 25 April and 2 May for egg mass ODSouth \#7-1, with three peaks on 25 April, 28 April, and 2 May; between 25-28 April for egg mass ODSouth \#7-2, with a single peak on 26 April; and on 29 April for egg mass ODSouth \#7-6 (Figure 2). For egg masses collected from oviposition site ODSouth \#8, adults emerged between 22 April and 2 May, with two peaks on 22 April and 28 April for egg mass ODSouth \#8-2; and between 25 April and 2 May, with a single peak on 25 April for egg mass ODSouth \#8-21 (Figure 2). 

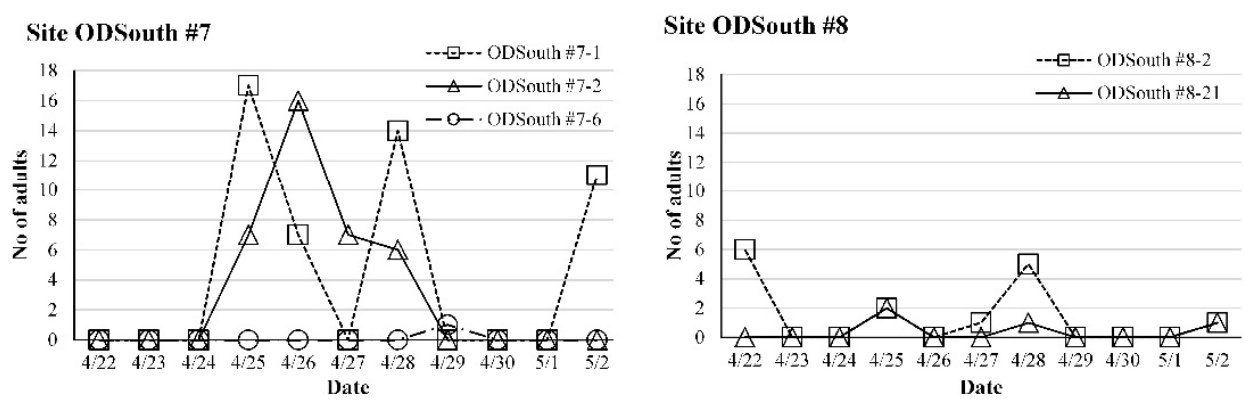

Figure 2. Seasonal abundance of $O$. kuvanae by egg mass on different oviposition sites based on laboratory incubation of L. delicatula eggs in 2016.

In 2017, O. kuvanae adult emergence started on 2 May and ended on 1 June based on field monitoring of the 41 selected L. delicatula eggs on four oviposition sites (A-D), with three overall peaks on 2, 11, and 30 May (Figure 3). For egg masses on oviposition site A, parasitoid adults emerged between 2 and 18 May, with three peaks on 2,11, and 18 May (Figure 3). For egg masses on oviposition site B, adults emerged between 8-11 May, with a single peak on 8 May (Figure 3). For egg masses on oviposition site C, adults emerged between 2-30 May, with three peaks on 2, 11, and 30 May (Figure 3). No significant emergence peak was observed for egg masses on oviposition site D, with an adult emergence period between 2 May to 1 June (Figure 3).
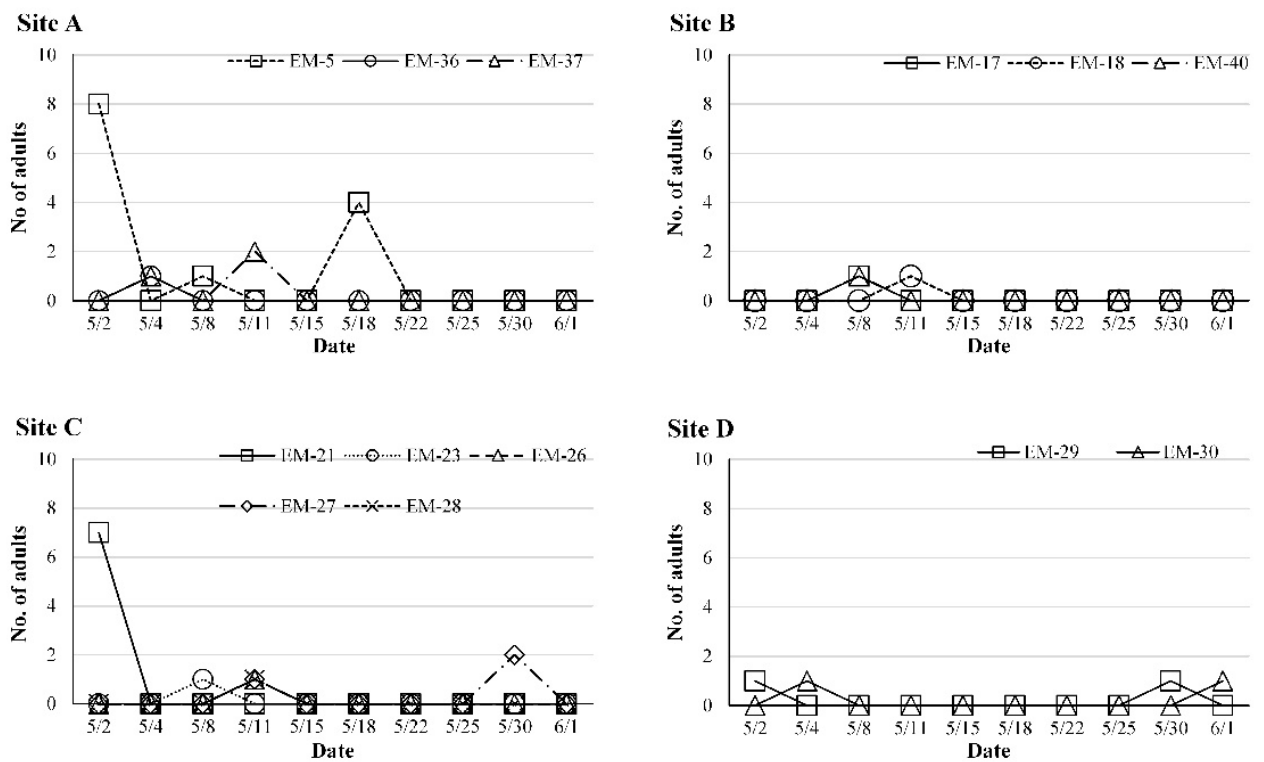

Figure 3. Seasonal abundance of $O$. kuvanae by egg mass on different oviposition sites based on field observation of L. delicatula eggs in 2017.

\subsection{Parasitism of O. kuvanae}

O. kuvanae parasitism was calculated only for study plot ODSouth, since no parasitized L. delicatula eggs were recovered from other plots. A total of $6.0 \%$ host egg masses (5/83) and 1.2\% (37/3013) host eggs were parasitized by $O$. kuvanae at this plot. Only two oviposition sites at plot ODSouth contained O. kuvanae-parasitized egg masses in 2016. The average parasitism by egg mass at this plot was $12.3 \%$, ranging from 9.5\% (ODSouth \#7) to 15.0\% (ODSouth \#8) (Table 2). Parasitism by egg for L. delicatula egg masses on oviposition site ODSouth \#7 ranged from $0 \%$ to $64 \%$, with an average of $5.0 \% \pm 45.3 \%$ (Table 2). Parasitism by egg for L. delicatula egg masses on oviposition site ODSouth \#8 ranged from $0 \%$ to $25 \%$, with an average of $1.3 \% \pm 5.5 \%$ (Table 2 ). The overall parasitism by egg was $3.1 \%$, with a 
significantly higher rate found on oviposition site ODSouth \#7 compared to ODSouth \#8 (Z-value = $-3.714, p<0.001$ ) (Table 2).

All four oviposition sites contained O. kuvanae-parasitized L. delicatula eggs in 2017 based on the results of field observations (Table 2). Parasitism by egg mass was $18.8 \%, 27.3 \%, 55.6 \%$, and $40.0 \%$ for oviposition sites A, B, C, and D, respectively (Table 2). Overall, $35.4 \%$ of egg masses on those oviposition sites were parasitized (Table 2). Parasitism by egg for L. delicatula egg masses for oviposition site A ranged from $0 \%$ to $25 \%$ with an average of $2.5 \%$, whereas the parasitism by egg was $0.5 \%(0-2.0 \%), 3.9 \%(0-21.2 \%)$, and $2.2 \%(0-8.7 \%)$ for oviposition sites $\mathrm{B}, \mathrm{C}$, and $\mathrm{D}$, respectively (Table 2). The overall parasitism by egg was $2.2 \%$, with no significant difference among oviposition sites $(Z$-value $=0.159, p=0.783)($ Table 2$)$.

\subsection{Superparasitism}

Superparasitism of O. kuvanae was observed on L. delicatula eggs through laboratory incubation based on parasitoid production and adult exit holes observed on parasitized host eggs. An O. kuvanae exit hole is round and about $0.5 \mathrm{~mm}$ in diameter, whereas a normal L. delicatula hatching hole is elongated and measures ca. $1.8 \times 0.5 \mathrm{~mm}$ (length $\times$ width) (Figure 4). A total of 103 (102 females and 1 male) O. kuvanae adults emerged from 37 parasitized L. delicatula eggs from 5 egg masses at plot ODSouth in 2016, with an average parasitoid production of 1.0 to 3.3 O. kuvanae adults/parasitized L. delicatula egg (Figure 5A). All but one egg mass (ODSouth \#7-6) contained parasitized L. delicatula eggs that produced multiple O. kuvanae adults per parasitized host egg (Figure 5A). A total of 49 O. kuvanae adults emerged from 16 parasitized L. delicatula eggs in egg mass ODSouth \#7-1, compared to 36 out of 11, 13 out of 7, 4 out of 2, and 1 out of 1 in egg masses ODSouth \#7-2,\#8-2, \#8-21, and \#7-6, respectively (Figure 5A). Superparasitism was not observed on egg mass ODSouth \#7-6 based on parasitoid production (Figure 5A).
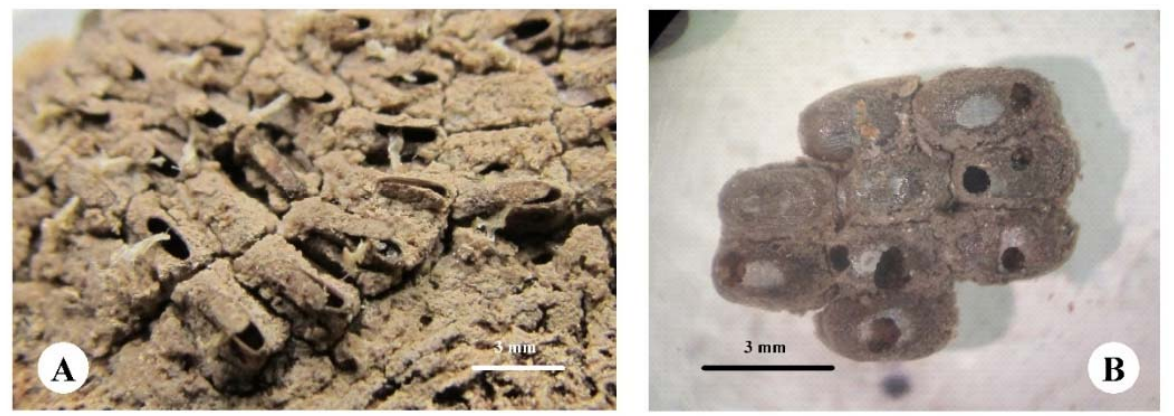

Figure 4. L. delicatula eggs with (A) normal hatching holes on the top and (B) O. kuvanae adult exit holes at the bottom.
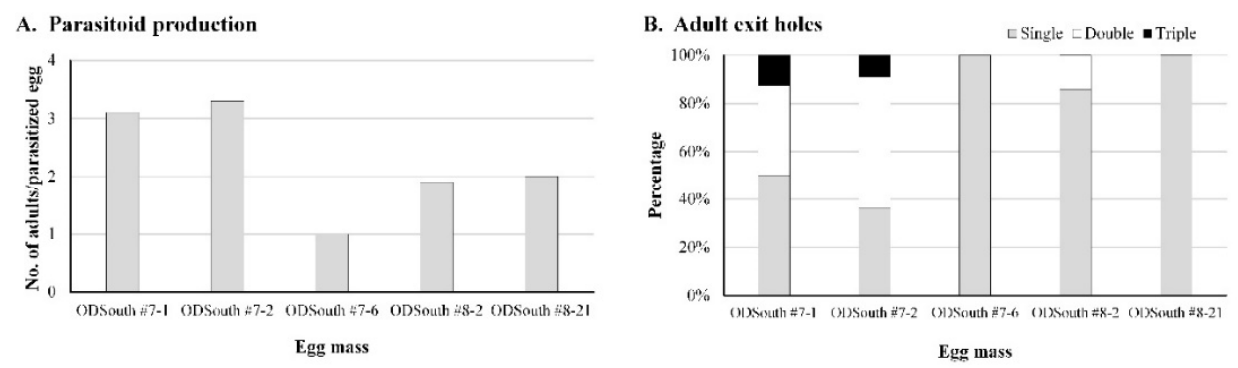

Figure 5. Superparasitism of O. kuvanae on L. delicatula eggs as indicated by (A) average parasitoid production per parasitized host egg and (B) percentage of parasitized host eggs with single/double/triple adult exit holes.

Superparasitism was also confirmed by the multiple O. kuvanae adult exit holes observed on some parasitized L. delicatula eggs after laboratory incubation (Figure 5B). Not all O. kuvanae adults created 
their own exit holes. The total number of exit holes observed on egg masses ODSouth \#7-1, \#7-2, \#8-2, \#8-21, and \#7-6 was 26, 19, 8, 2, and 1, respectively. These numbers were generally lower than the total number of parasitoid adults that emerged from the respective egg masses reported above, except for egg mass ODSouth \#7-6. For the 16 parasitized eggs in egg mass ODSouth \#7-1, 12.5\% contained triple exit holes, 37.5\% contained double exit holes, and 50\% contained single exit holes (Figure 5B). This ratio was $9.1 \%, 54.5 \%$, and $36.4 \%$, respectively, for egg mass ODSouth \#7-2, where 11 of its 30 eggs were parasitized (Figure 5B). No triple exit holes were found on egg masses ODSouth \#8-2, \#8-21, or \#7-6. Both double and single exit holes were observed on parasitized L. delicatula eggs from egg mass ODSouth \#8-2, accounting for $14.3 \%$ and $85.7 \%$, respectively (Figure 5B). Only single exit holes were observed for parasitized L. delicatula eggs in egg masses ODSouth \#7-6 and \#8-21 (Figure 5B). Superparasitism was not observed in egg masses ODSouth \#7-6 and \#8-21 based on the number of adult exit holes.

\section{Discussion}

The status of L. delicatula as a major forest pest in North America is still under evaluation despite observations of its feeding on other important crops such as apple and hops (so far). Tree-of-heaven, a small- to medium-sized invasive species native to China [37], was first introduced to North America from Europe as an ornamental in 1784 [38]. It is now generally considered to be a noxious plant that is widely distributed across the continent, from southern Ontario to Florida and British Columbia to southern California $[39,40]$. Any negative impact of L. delicatula on tree-of-heaven could potentially be welcomed in many states. However, it is the feeding of L. delicatula on other major tree species that concerns forest managers and forest health professionals. Feeding damage in the field has been observed on Chinese mahogany (Toona sinensis (A. Juss) M. Roem) in China [41] and on northern red oak, black walnut, silver maple, and bigtooth aspen (Populus grandidentata Michaux) in Pennsylvania [42]. Laboratory rearing results have shown that L. delicatula can develop into adults from first instar nymphs on black walnut, tulip trees, chinaberry (Melia azedarach L.), butternut (Juglans cinerea L.), sawtooth oak (Quercus acutissima Carruth), or weeping willow (Salix babylonica L.), exclusively [41,43]. More species could be added to this list as host range studies continue.

Current management approaches for L. delicatula in Pennsylvania include silvicultural, mechanical, and chemical control [44]. Silvicultural control focuses on host removal through cutting and chipping and herbicide treatment of tree-of-heaven inside the infestation. Chipping infested material into standard one-inch in two-dimension chip sizes in mid-winter destroyed all L. delicatula eggs [45]. Mechanical control targets L. delicatula eggs or nymphs through egg scaping and tree banding. Chemical control is generally used to treat a few trap trees in each management area with systemic insecticides such as dinotefuran and imidacloprid to kill feeding L. delicatula nymphs and adults. While all of them may be effective in localized areas, the long-term management of L. delicatula in North America relies on biological control in the absence of an effective insecticide that can be broadcast over large areas.

The natural enemies of L. delicatula in its native range include Anastatus orientalis Yang and Choi (Hymenoptera: Eupelmidae), a solitary egg parasitoid [46,47]; and Dryinus browni Ashmead (Hymenoptera: Dryinidae), a solitary nymphal ectoparasitoid [48]. Field parasitism in China has ranged from $30.5 \%$ to $69.0 \%$ (by egg mass) and $33.0 \%$ to $40.2 \%$ (by egg) for An. orientalis [46,47] and from $12.5 \%$ to $43.5 \%$ for D. browni, respectively [48]. An unidentified Anastatus species, possibly An. orientalis, was also reported in Korea, where an invasion of L. delicatula occurred in 2004 [49]. In China, an unidentified species of Epipyropidae was recovered from L. delicatula nymphs on traps in the field [41]. An. orientalis is currently being evaluated by USDA researchers as a potential agent for the classical biological control of L. delicatula in North America.

The recently discovered new association between $O$. kuvanae and L. delicatula could open doors for the biological control of this pest in North America [27]. The new association approach in biological control utilizes natural enemies that have not co-evolved with the pest. It has been considered more effective than the traditional approach (where co-evolved natural enemies are used) by some 
due to higher host vulnerability to novel agents [50-53]. O. kuvanae is commonly found on gypsy moth eggs across the eastern United States, exerting a parasitism rate of $10 \%-40 \%[25,54]$. Factors limiting its efficacy on gypsy moths include high overwintering adult mortality, poor dispersal ability, and a short ovipositor that prevents females from reaching host eggs beyond the upper layer in the egg masses $[24,25,55]$. In the current study, O. kuvanae adults were collected from L. delicatula egg mass surfaces at two study plots in the field and reared from eggs collected at one study plot in the laboratory in 2016. The overall parasitism on L. delicatula at this site (1.2\%) was low compared to that on gypsy moths, although a higher rate was observed on specific egg masses and oviposition sites (Table 2). Localized high parasitism rates are common for invasive pests by new association native or exotic parasitoids. In Michigan, a native solitary parasitoid, Atanycolus cappaerti Marsh and Strazanac (Hymenoptera: Braconidae), was found to be parasitizing $56 \%-71 \%$ of larvae of the invasive emerald ash borer Agrilus planipennis Fairmare (Coleoptera: Buprestidae) at one plot [56]. In Alabama, an average parasitism rate of $95.6 \%$ was observed at a single study plot for Ooencyrtus nezarae Ishii (Hymenoptera: Encyrtidae), a facultative gregarious egg parasitoid from Asia, on the kudzu bug (Megacopta cribraria (F.) (Hemiptera: Plataspidae)) [57]. More exposure of L. delicatula eggs to O. kuvanae over time in the field could result in higher parasitism in the future.

O. kuvanae adult emergence occurred a week after the initial hatching of L. delicatula eggs and lasted for about a month based on the results of laboratory incubation [42]. In the laboratory at $22 \pm 1{ }^{\circ} \mathrm{C}, 40 \% \pm 5 \%$ relative humidity, and a photoperiod of $16: 8$ (light/dark) h, adult emergence occurred between 22 April and 2 May in 2016, with peak emergence on days 3, 8, and 11, respectively (Figure 2). Similar peak emergence between day 2 and day 9 was also observed for this parasitoid on its substitute host $P$. ricini when reared at $25 \pm 1{ }^{\circ} \mathrm{C}, 65 \% \pm 5 \%$ relative humidity, and a photoperiod of 16:8 (light/dark) in laboratory incubation [58]. A development time from egg to adult of 21 days at $25^{\circ} \mathrm{C}$ was recorded on gypsy moths [24], compared to a developmental period of 16.5-18.7 days at the same temperature on P. ricini [58]. Differences in host species and incubation temperatures could explain the discrepancies between different studies.

The results of seasonal abundance studies showed that $O$. kuvanae synchronized well with overwintering L. delicatula eggs in the field in the spring, with adult emergence observed between 2 May and 1 June in 2017 (Figure 3). L. delicatula egg hatching started on 2 May and ended on 5 June in 2017 [42]. O. kuvanae overwinters as fertilized adult females in forest litter layers and completes at least four generations per year in the field [24]. Females can parasitize infertile, developed, unhatched, or even recently killed gypsy moth eggs [20,59]. They become active in mid-April and lay eggs on overwintering host eggs. Adults of the first spring generation emerge in late May to early June to parasitize suitable unhatched gypsy moth eggs. Adults of the second spring generation appear in July for the new gypsy moth eggs. Parasitoid populations reach peak levels in August and September for the first and second summer generations before declining rapidly toward November as adults prepare to overwinter $[24,54,59,60]$. Despite obvious similarities in life history traits (e.g., voltinism, overwintering patterns, egg site selection) between L. delicatula and gypsy moths, there are significant differences in metamorphosis, host plants, and egg period that could potentially alter the behavior of O. kuvanae as an egg parasitoid of L. delicatula in North America. Under current conditions, the new L. delicatula eggs laid in October might not be favored by $O$. kuvanae females as they prepare for overwintering. However, a gradual shift of egg period from October to December [6] to August to October that has been observed in Asia $[14,16]$ could be beneficial to O. kuvanae as an important biological control agent of L. delicatula in North America. Whether this shift will occur remains to be seen. Chances of multiple O. kuvanae generations on L. delicatula in the field will depend on its adaptive response to the biological features of L. delicatula eggs. Periodic sampling on both new and overwintering host eggs from the field could shed more light on this.

Superparasitism was observed for O. kuvanae on L. delicatula eggs based on evidence of average parasitoid production and adult exit holes on single host eggs (Figures 4 and 5). The sex ratio for its offspring was extremely female-biased. It is unclear whether this was self- or conspecific superparasitism 
and why it occurred on L. delicatula eggs in the field. Self-superparasitism in solitary parasitoids is considered a waste of energy, as only one parasitoid individual survives in the end, whereas conspecific superparasitism can be advantageous under certain circumstances, since non-sibling competitors could be eliminated from parasitized hosts [28]. The benefits of increased numbers of offspring through superparasitism is usually negated by the deleterious effects on progeny fitness (i.e., prolonged development time, a smaller body size, a male-biased sex ratio, and decreased longevity) $[28,33,61]$. The tendency to superparasitize by parasitoids is largely determined by female age and host density, as older females and lower host densities tend to result in attacks on already parasitized hosts [33,62,63]. As a solitary arrhenotokous egg parasitoid, O. kuvanae has superparasitized larger hosts under laboratory conditions [33]. However, this phenomenon has not been reported from the field before. The same factors may not be sufficient to explain the field superparasitism on L. delicatula observed in this study, since plenty of unparasitized host eggs were available in the environment, and the old parasitoid females, after overwintering, did not superparasitize gypsy moth eggs based on other studies. One can point to the difference in egg size between the two species from a resource exploitation point of view. An L. delicatula egg is cylindrical, with measurements of $1.5 \times 3.0 \mathrm{~mm}$ (diameter $\times$ height) [3], whereas a gypsy moth egg is oval, with a diameter of $1 \mathrm{~mm} \mathrm{[23].} \mathrm{It} \mathrm{contains} \mathrm{about}$ 10 times the nutrition to support the development of multiple O. kuvanae individuals. Another explanation could be encapsulation evasion, where multiple parasitoids can better overcome a host's immune system, especially for solitary species [28]. Field superparasitism has also been reported for Diachasmimorpha longicaudata (Ashmead) (Hymenoptera: Braconidae), a solitary larval-pupal parasitoid of the Mexican fruit fly Anastrepha ludens (Loew) (Diptera: Tephritidae) [64]; and Phymastichus coffea LaSalle (Hymenoptera: Eulophidae), a gregarious endoparasitoid of the female coffee berry borer Hypothenemus hampei (Ferrari) (Coleoptera: Curculionidae) [65].

It is possible for other native natural enemy species to start their own new associations with L. delicatula in the future, just like O. kuvanae did. An unidentified species of Dryinidae was found attacking L. delicatula nymphs in Berks county in 2016 [42]. There are approximately 143 genera and 716 species in the Fulgoridae family worldwide, with all Lycorma species found in Asia [66]. In the Americas north of Mexico, this family is represented by 17 species in 9 genera [67]. None had been found in Pennsylvania prior to the introduction of L. delicatula in 2014 . However, the planthopper parasitoid Fulgoraecia exigua (H. Edwards) (Lepidoptera: Epipyropidae) has been recorded in Pennsylvania [68]. Time will tell whether it can switch to L. delicatula in Pennsylvania in the future.

\section{Conclusions}

O. kuvanae is the first parasitoid recorded on L. delicatula in North America, with a life cycle well synchronized with overwintering L. delicatula eggs in the spring. As a solitary arrhenotokous egg parasitoid, it can superparasitize L. delicatula eggs in the field and result in a female-biased progeny population. It has great potential as an important biological control agent for the management of L. delicatula in North America. Compared to the gypsy moth, L. delicatula provides some unique opportunities (e.g., a single-layer egg mass, larger eggs) and challenges (e.g., a late egg period) as a host for O. kuvanae to complete its life cycle in the field. They could complement each other as alternative hosts for $O$. kuvanae in the future. One advantage of this parasitoid over other exotic natural enemies (e.g., An. orientalis) being considered for L. delicatula biological control is its century-long field establishment in North America, which makes it readily available for use in potential augmentation and conservation biological controls. Its success on gypsy moths as an effective biological control agent could well be translated to L. delicatula. Past experiences with it in biology studies, laboratory rearing techniques, field release protocols, and recovery confirmation methodologies against the gypsy moth could be very helpful in the future utilization of O. kuvanae in the biological control of L. delicatula. Concerns over nontarget impacts in North America will be minimized, since no hosts other than the gypsy moth have been recorded from the field. The relatively low field parasitism and apparent lack 
of synchronization with host eggs in the fall could be overcome with time and more studies on its life history, field host range, attacking patterns, consequences of superparasitism, and host biology and seasonal development.

Author Contributions: H.L. was responsible for the study conceptualization, methodology, funding acquisition, investigation, work supervision, formal analysis, draft preparation, and manuscript reviewing and editing.

Funding: This research was partially funded by the USDA-APHIS-PPQ Cooperative Agreement 16-8130-0655-CA and Farm Bill \#AP17PPQS\&T00C057.

Acknowledgments: I thank Mary Rose, George Lang, Steffan Helbig, Gary Weller, Mancini Robert, Dave Straub, Laszlo Lengyel, Paul Gierschick, William Blair, Adrianne Blank, Steve Moyer, Frank Morgan, Louis Farina, and Piper Sherbourne for access to the study plots; Gina Peters, Paul Smith, Zachary Clemens, Brian Liu, and Mark Faulkenberry for laboratory and field assistance; Kenneth Duren for assistance in data analysis; Fengyou Jia for help with study plot map creation; Sven-Erik Spichiger and John Baker (Pennsylvania Department of Agriculture) for logistical support, ailanthus distribution, and treatment information on study plots; Kathy Tatman (USDA-ARS Beneficial Insects Introduction Research) for laboratory assistance and use of quarantine facilities from April to May in 2016; and two anonymous reviewers for valuable comments.

Conflicts of Interest: The author declares no conflict of interest.

\section{References}

1. White, A. Description of a new genus and some new species of homopterous insects from the East in the collection of British Museum. Ann. Mag. Nat. Hist. 1845, 15, 34-37. [CrossRef]

2. Liu, G. Some extracts from the history of entomology in China. Psyche 1939, 46, 23-28. [CrossRef]

3. Zhou, J.X. Lycorma delicatula (White) (Homoptera: Fulgoridae). In Forest Insects of China, 2nd ed.; Xiao, G.R., Ed.; Chinese Forestry Publishing House: Beijing, China, 1992; pp. 169-170.

4. Han, J.M.; Kim, H.J.; Lim, E.J.; Lee, S.H.; Kwon, Y.J.; Cho, S.W. Lycorma delicatula (Hemiptera: Auchenorrhyncha: Fulgoridae: Aphaeninae) finally, but suddenly arrived in Korea. Entomol. Res. 2008, 38, 281-286. [CrossRef]

5. Barringer, L.E.; Donovall, L.R.; Spichiger, S.-E.; Lynch, D.; Henry, D. The first New World record of Lycorma delicatula (Insecta: Hemiptera: Fulgoridae). Entomol. News 2015, 125, 20-23. [CrossRef]

6. Dara, S.K.; Barringer, L.; Arthurs, S.P. Lycorma delicatula (Hemiptera: Fulgoridae): A new invasive pest in the United States. J. Integr. Pest Manag. 2015, 6, 20. [CrossRef]

7. Pennsylvania Department of Agriculture. Spotted Lanternfly. Available online: https://www.agriculture.pa. gov /Plants_Land_Water/PlantIndustry/Entomology/spotted_lanternfly/Pages/default.aspx (accessed on 21 November 2018).

8. Virginia Cooperative Extension. Spotted Lanternfly in Virginia. Available online: https://ext.vt.edu/ agriculture/commercial-horticulture/spotted-lanternfly.html (accessed on 21 November 2018).

9. New Jersey Department of Agriculture. Spotted Lanternfly. Available online: https://www.nj.gov/ agriculture/divisions/pi/prog/spottedlanternfly.html (accessed on 21 November 2018).

10. New York Department of Environmental Conservation. Spotted Lanternfly. Available online: http://www. dec.ny.gov/animals/113303.html (accessed on 21 November 2018).

11. Delaware Department of Agriculture. Spotted Lanternfly. Available online: https:/ /agriculture.delaware. gov/plant-industries/spotted-lanternfly / (accessed on 21 November 2018).

12. Kim, J.; Lee, E.H.; Seo, Y.M.; Kim, N.Y. Cyclic behavior of Lycorma delicatula (Insecta: Hemiptera: Fulgoridae) on host plants. J. Insect Behav. 2011, 24, 423-435. [CrossRef]

13. Lee, J.E.; Moon, S.R.; Ahn, H.G.; Cho, S.R.; Yang, J.O.; Yoon, C.; Kim, J.H. Feeding behavior of Lycorma delicatula (Hemiptera: Fulgoridae) and response on feeding stimulants of some plants. Korean J. Appl. Entomol. 2009, 48, 467-477. [CrossRef]

14. Park, J.D.; Kim, M.Y.; Lee, S.G.; Shin, S.C.; Kim, J.H.; Park, I.K. Biological characteristics of Lycorma delicatula and the control effects of some insecticides. Korean J. Appl. Entomol. 2009, 48, 53-57. [CrossRef]

15. Pennsylvania Department of Agriculture. PA Agriculture Department Adds Seven Counties to Spotted Lanternfly Quarantine Zone. Available online: http://www.media.pa.gov/pages/Agriculture_details.aspx? newsid=616 (accessed on 28 September 2018). 
16. Lee, K.Y.; Kim, S.K.; Kim, I.H.; Kim, K.S. Seasonal occurrence of spot clothing wax cicada, Lycorma delicatula (Hemiptera: Fulgoridae) and its control efficacy using EFAM at the vineyards. Korean J. Pestic. Sci. 2011, 15, 303-309.

17. Howard, L.O. Technical results from the gypsy moth parasite laboratory. I. The parasites reared or supposed to have been reared from the eggs of gypsy moth. U.S. Dep. Agric. Tech. Ser. Bull. 1910, 19, 1-12.

18. Hirose, Y. The activity of the egg parasites of the pinemoth, Dendrolimus spectabilis Butler, in Japanese black pine forest on the seacoast. Sci. Bull. Fac. Agric. Kyushi Univ. 1964, 21, 13-24.

19. Koidzumi, K.; Shobata, K. Studies on Eriogyna pyretorum Westwood and its fishing thread. XI. Epiparasites. J. Soc. Trop. Agric. Formosa 1940, 12, 259-265.

20. Howard, L.O.; Fiske, W.F. The Importation into the United States of the Parasites of the Gypsy Moth and the Brown-Tailed Moth: A Report of Progress with Some Consideration of Previous and Concurrent Efforts of this Kind; USDA: Washington, DC, USA, 1911.

21. Muesebeck, C.F.W.; Dohanian, S.M. A Study in Hyperparasitism with Particular Reference to the Parasites of Apanteles melanoscelus (Ratzeburg); USDA: Washington, DC, USA, 1927.

22. Crossman, S.S. Some methods of colonizing imported parasites and determining their increase and spread. J. Econ. Entomol. 1917, 10, 177-183. [CrossRef]

23. Britton, W.E. The gypsy moth. Conn. Agric. Exp. Stn. Bull. 1935, 375, 625-647.

24. Crossman, S.S. Two imported egg parasites of the gypsy moth, Anastatus bifasciatus Fonsc. and Schedius kuvanae Howard. J. Agric. Res. 1925, 30, 643-675.

25. Brown, M.W. Literature review of Ooencyrtus kuvanae (Hym.: Encyrtidae), an egg parasite of Lymantria dispar (Lep.: Lymantriidae). Entomophaga 1984, 29, 249-265. [CrossRef]

26. Smilowitz, Z.; Rhoads, L. An assessment of gypsy moth natural enemies in Pennsylvania. Environ. Entomol. 1973, 2, 797-799. [CrossRef]

27. Liu, H.P.; Mottern, J. An old remedy for a new problem? Identification of Ooencyrtus kuvanae (Hymenoptera: Encyrtidae), an egg parasitoid of Lycorma delicatula (Hemiptera: Fulgoridae) in North America. J. Insect Sci. 2017, 17, 1-6. [CrossRef]

28. van Alphen, J.J.M.; Visser, M.E. Superparasitism as an adaptive strategy for insect parasitoids. Annu. Rev. Entomol. 1990, 35, 59-79. [CrossRef]

29. Gandon, S.; Rivero, A.; Varaldi, J. Superparasitism evolution: Adaptation and manipulation? Am. Nat. 2006, 176, 1-22. [CrossRef]

30. Godfray, H.C.J. Parasitoids: Behavioral and Evolutionary Ecology; Princeton University Press: Princeton, NJ, USA, 1994.

31. Gu, H.; Wang, Q.; Dorn, S. Superparasitism in Cotesia glomerata: Response of hosts and consequences for parasitoids. Ecol. Entomol. 2003, 28, 422-431. [CrossRef]

32. Dorn, S.; Beckage, N. Superparasitism in gregarious hymenopteran parasitoids: Ecological, behavioural and physiological perspectives. Physiol. Entomol. 2007, 32, 199-211. [CrossRef]

33. Tunca, H.; Colombel, E.-A.; Venard, M.; Tabone, E. Incidence of superparasitism in the egg parasitoid, Ooencyrtus kuvanae Howard (Hymenoptera: Encyrtidae). Biocontrol Sci. Technol. 2017, 27, 796-808. [CrossRef]

34. Hofstetter, R.W.; Raffa, K.F. New host record for Ooencyrtus kuvanae (Hymenoptera: Encyrtidae). Entomol. News 1997, 108, 63-65.

35. Huang, D.W.; Noyes, J.S. A revision of the Indo-Pacific species of Ooencyrtus (Hymenoptera: Encyrtidae), parasitoids of the immature stages of economically important insect species (mainly hemipteran and Lepidoptera). Bull. Nat. Hist. Mus. Lond. 1994, 63, 1-136.

36. R Core Team. R: A Language and Environment for Statistical Computing. R Foundation for Statistical Computing: Vienna, Austria. Available online: http:/ / www.R-project.org/ (accessed on 27 November 2018).

37. Hu, S. Ailanthus. Arnoldia 1979, 39, 29-50.

38. Swingle, W.T. The early European history and the botanical name of the tree-of-heaven, Ailanthus altissima. J. Wash. Acad. Sci. 1916, 6, 409-498.

39. Zasada, J.C.; Little, S. Ailanthus altissima (P. Mill.) Swingle: Ailanthus. In Woody Plant Seed Manual; Agric. Handbook No. 727; Bonner, F.T., Karrfalt, R.P., Eds.; USDA Forest Service: Washington, DC, USA, 2008; pp. 224-226. 
40. Howard, J.L. Ailanthus altissima. In Fire Effects Information System; USDA Forest Service, Rocky Mountain Research Station, Fire Sciences Laboratory, 2004. Available online: https: / /www.fs.fed.us / database/feis / plants/tree/ailalt/all.html (accessed on 29 October 2018).

41. Cooperband, M.F.; USDA APHIS, Buzzards Bay, MA, USA. Personal communication, 2018.

42. Liu, H.-P.; Pennsylvania Department of Conservation and Natural Resources, Harrisburg, PA, USA. Personal observation, 2018.

43. Hoover, K.; Pennsylvania State University, State College, PA, USA. Personal communication, 2018.

44. Leach, H.; Krawczyk, G. Spotted Lanternfly Management for Homeowners. Penn State Extension: State College, PA, USA. Available online: https://extension.psu.edu/spotted-lanternfly-managementfor-homeowners (accessed on 31 October 2018).

45. Cooperband, M.F.; Mack, R.; Spichiger, S.-E. Chipping to destroy egg masses of the spotted lanternfly, Lycorma delicatula (Hempitera: Fulgoridae). J. Insect Sci. 2018, 18, 1-3. [CrossRef]

46. Yang, Z.-Q.; Choi, W.-Y.; Cao, L.-M.; Wang, X.-Y.; Hou, Z.-R. A new species of Anastatus (Hymenoptera: Eulpelmidae) from China, parasitizing eggs of Lycorma delicatula (Homoptera: Fulgoridae). Zool. Syst. 2015, 40, 290-302.

47. Choi, M.-Y.; Yang, Z.-Q.; Wang, X.-Y.; Hou, Z.-R.; Kim, J.H.; Byeon, Y.W. Parasitism rate of egg parasitoid Anastatus orientalis (Hymenoptera: Eupelmidae) on Lycorma delicatula (Hemiptera: Fulgoridae) in China. Korea J. Appl. Entomol. 2014, 53, 135-139. [CrossRef]

48. Yan, J.H.; Yu, X.M.; Qin, X.B.; Wang, F.Y.; Bo, L.L. Study on the biology of Dryinus browni. Shandong For. Sci. Technol. 2008, 1, 16-18.

49. Kim, I.-K.; Koh, S.-H.; Lee, J.-S.; Choi, W.I.; Shin, S.-C. Discovery of an egg parasitoid of Lycorma delicatula (Hemiptera: Fulgoridae) an invasive species in South Korea. J. Asia Pac. Entomol. 2015, 14, $213-215$. [CrossRef]

50. Hokkanen, H.; Pimentel, D. New approach for selecting biological control agents. Can. Entomol. 1984, 116, 1109-1121. [CrossRef]

51. Hokkanen, H.; Pimentel, D. New associations in biological control: Theory and practice. Can. Entomol. 1989, 121, 829-840. [CrossRef]

52. Irvin, N.A.; Hoddle, M.S. Comparative assessments of Gonatocerus ashmeadi and the 'new association' parasitoid Gonatocerus tuberculifemur (Hymenoptera: Mymaridae) as biological control agents of Homalodisca vitripennis (Hemiptera: Cicadellidae). Biol. Control 2010, 55, 186-196. [CrossRef]

53. O'Connell, D.M.; Wratten, S.D.; Pugh, A.R.; Barnes, A.-M. 'New species association' biological control? Two coccinellid species and an invasive psyllid pest in New Zealand. Biol. Control 2012, 62, 86-92. [CrossRef]

54. Brown, M.W.; Cameron, E.A.; Williams, F.M. Population model for the gypsy moth (Lepidoptera: Lymantriidae) egg parasite, Ooencyrtus kuvanae (Hymenoptera: Encyrtidae). Environ. Entomol. 1982, 11, 1299-1304. [CrossRef]

55. Hofstetter, R.W.; Raffa, K.F. Endogenous and exogenous factors affecting parasitism of gypsy moth egg masses by Ooencyrtus kuvanae. Entomol. Exp. Appl. 1998, 88, 123-135. [CrossRef]

56. Cappaert, D.; McCullough, D.G. Occurrence and seasonal abundance of Atanycolus cappaerti (Hymenoptera: Braconidae), a native parasitoid of emerald ash borer, Agrilus planipennis (Coleoptera: Buprestidae). Great Lakes Entomol. 2009, 42, 16-29.

57. Ademokoya, B.; Balusu, R.; Ray, C.; Mottern, J.; Fadamiro, H. The first record of Ooencyrtus nezarae (Hymenoptera: Encyrtidae) on kudzu bug (Hemiptera: Plataspidae) in North America. J. Insect Sci. 2018, 18, 1-7. [CrossRef]

58. Tunca, H.; Venard, M.; Colombel, E.-A.; Tabone, E. A new substitute host and its effects on some biological properties of Ooencyrtus kuvanae. Bull. Entomol. Res. 2017, 107, 742-748. [CrossRef] [PubMed]

59. Parker, D.L. The interactions of two hymenopterous egg parasites of the gipsy moth, with notes on the larval instars of each. J. Agric. Res. 1933, 46, 23-34.

60. Weseloh, R.M. Spatial distribution of the gypsy moth (Lepidoptera: Lymantriidae) and some of its parasitoids within the forest environment. Entomophaga 1972, 17, 339-351. [CrossRef]

61. Zhang, B.; Li, B.-P.; Meng, L. Effects of self-superparasitism and host age on fitness-correlated traits in solitary endoparasitoid wasp Meteorus pulchricornis. J. Insect Sci. 2014, 14, 1-11. 
62. Tunca, H.; Buradino, M.; Colombel, E.-A.; Tabone, E. Tendency and consequences of superparasitism for the parasitoid Ooencyrtus pityocampae (Hymenoptera: Encyrtidae) in parasitizing a new laboratory host, Philosamia ricini (Lepidoptera: Saturniidae). Eur. J. Entomol. 2016, 113, 51-59. [CrossRef]

63. Tunca, H.; Colombel, E.-A.; Buradino, M.; Galio, F.; Tabone, E. Optimal biological parameters for rearing Ooencyrtus pityocampae on the new laboratory host Philosamia ricini. J. Appl. Entomol. 2015, 140, 1-9.

64. Montoya, P.; Perez-Lachaud, G.; Liedo, P. Superparasitism in the fruit fly parasitoid Diachasmimorpha longicaudata (Hymenoptera: Braconidae) and the implications for mass rearing and augmentative release. Insects 2012, 3, 900-911. [CrossRef]

65. Jaramillo, J.; Borgemeister, C.; Setamou, M. Field superparasitism by Phymastichus coffea, a parasitoid of adult coffee berry borer Hypothenemus hampei. Entomol. Exp. Appl. 2006, 119, 231-237. [CrossRef]

66. Bourgoin, T. FLOW (Fulgoromorpha Lists on The Web): A Knowledge and a Taxonomy Database Dedicated to Planthoppers (Insecta, Hemiptera, Fulgoromorpha, Fulgoroidea) Version 8. French National Museum of Natural History: Paris, France. Available online: https://www.hemiptera-databases.org/flow/ (accessed on 29 October 2018).

67. Bartlett, C.R.; O'Brien, L.B.; Wilson, S.W. A review of the planthoppers (Hemiptera: Fulgoroidea) of the United States. Mem. Am. Entomol. Soc. 2014, 50, 1-287.

68. Planthopper Parasite Moth, Fulgoraecia exigua (H. Edwards, 1882). Butterflies and Moths of North America. Available online: https://www.butterfliesandmoths.org/species/Fulgoraecia-exigua (accessed on 14 November 2018).

(C) 2019 by the author. Licensee MDPI, Basel, Switzerland. This article is an open access article distributed under the terms and conditions of the Creative Commons Attribution (CC BY) license (http://creativecommons.org/licenses/by/4.0/). 